\title{
The Microaerophilic Microbiota of De-Novo Paediatric Inflammatory Bowel Disease: The BISCUIT Study
}

\author{
Richard Hansen ${ }^{1,2}$, Susan H. Berry ${ }^{1}$, Indrani Mukhopadhya ${ }^{1}$, John M. Thomson ${ }^{1}$, Karin A. Saunders ${ }^{1}$, \\ Charlotte E. Nicholl ${ }^{1}$, W. Michael Bisset ${ }^{3}$, Sabarinathan Loganathan ${ }^{3}$, Gamal Mahdi ${ }^{3}$, Dagmar Kastner- \\ Cole $^{4}$, Andy R. Barclay ${ }^{5}$, Jon Bishop ${ }^{5}$, Diana M. Flynn ${ }^{5}$, Paraic McGrogan ${ }^{5}$, Richard K. Russell ${ }^{5}$, Emad M. El- \\ Omar', Georgina L. Hold ${ }^{1}$ *
}

1 Gastrointestinal Research Group, Division of Applied Medicine, University of Aberdeen, Foresterhill, Aberdeen, United Kingdom, 2 Child Health, University of Aberdeen, Royal Aberdeen Children's Hospital, Foresterhill, Aberdeen, United Kingdom, 3 Department of Paediatric Gastroenterology, Royal Aberdeen Children's Hospital, Foresterhill, Aberdeen, United Kingdom, 4 Department of Paediatrics, Ninewells Hospital and Medical School, Dundee, United Kingdom, 5 Department of Paediatric Gastroenterology, Royal Hospital for Sick Children, Glasgow, United Kingdom

\begin{abstract}
Introduction: Children presenting for the first time with inflammatory bowel disease (IBD) offer a unique opportunity to study aetiological agents before the confounders of treatment. Microaerophilic bacteria can exploit the ecological niche of the intestinal epithelium; Helicobacter and Campylobacter are previously implicated in IBD pathogenesis. We set out to study these and other microaerophilic bacteria in de-novo paediatric IBD.

Patients and Methods: 100 children undergoing colonoscopy were recruited including 44 treatment naïve de-novo IBD patients and 42 with normal colons. Colonic biopsies were subjected to microaerophilic culture with Gram-negative isolates then identified by sequencing. Biopsies were also PCR screened for the specific microaerophilic bacterial groups: Helicobacteraceae, Campylobacteraceae and Sutterella wadsworthensis.

Results: 129 Gram-negative microaerophilic bacterial isolates were identified from 10 genera. The most frequently cultured was S. wadsworthensis (32 distinct isolates). Unusual Campylobacter were isolated from 8 subjects (including 3 C. concisus, 1 C. curvus, 1 C. lari, 1 C. rectus, 3 C. showae). No Helicobacter were cultured. When comparing IBD vs. normal colon control by PCR the prevalence figures were not significantly different (Helicobacter $11 \%$ vs. $12 \%, p=1.00$; Campylobacter $75 \%$ vs. $76 \%$, $\mathrm{p}=1.00 ;$ S. wadsworthensis $82 \%$ vs. $71 \%, \mathrm{p}=0.312$ ).

Conclusions: This study offers a comprehensive overview of the microaerophilic microbiota of the paediatric colon including at IBD onset. Campylobacter appear to be surprisingly common, are not more strongly associated with IBD and can be isolated from around $8 \%$ of paediatric colonic biopsies. S. wadsworthensis appears to be a common commensal. Helicobacter species are relatively rare in the paediatric colon.
\end{abstract}

Trial Registration: This study is publically registered on the United Kingdom Clinical Research Network Portfolio (9633).

Citation: Hansen R, Berry SH, Mukhopadhya I, Thomson JM, Saunders KA, et al. (2013) The Microaerophilic Microbiota of De-Novo Paediatric Inflammatory Bowel Disease: The BISCUIT Study. PLoS ONE 8(3): e58825. doi:10.1371/journal.pone.0058825

Editor: Stefan Bereswill, Charité-University Medicine Berlin, Germany

Received December 20, 2012; Accepted February 7, 2013; Published March 12, 2013

Copyright: (c) 2013 Hansen et al. This is an open-access article distributed under the terms of the Creative Commons Attribution License, which permits unrestricted use, distribution, and reproduction in any medium, provided the original author and source are credited.

Funding: This work was funded by a Clinical Academic Training Fellowship from the Chief Scientist Office in Scotland (CAF/08/01) which also funded the salary of $\mathrm{RH}$. The Royal Hospital for Sick Children, Glasgow IBD team is generously supported by the Catherine McEwan Foundation and the Yorkhill IBD fund. RKR is supported by an NHS Research Scotland career fellowship award. The funders had no role in study design, data collection and analysis, decision to publish, or preparation of the manuscript.

Competing Interests: Georgina Hold is a PLOS ONE Editorial Board member. This does not alter the authors' adherence to all the PLOS ONE policies on sharing data and materials.

*E-mail: g.l.hold@abdn.ac.uk

\section{Introduction}

Paediatric inflammatory bowel disease (IBD) represents a variant phenotype characterised by more extensive disease activity at onset and a progressive course [1]. Immunological differences can be identified between paediatric and adult Crohn's disease (CD) [2]. While paediatric disease represents a distinct phenotype of IBD, it is surprisingly not explained by a significantly different genotype [3]. One implication might be that the paediatric phenotype is an expression of different environmental triggers rather than inherited factors. Recent studies showing a rise in the incidence of IBD in childhood and, perhaps more worryingly, a younger age at onset in those affected support an urgent need for aetiological studies to explain these trends [4-7]. The discovery that the use of antibiotics early in life and in multiple courses confers an increased risk of subsequent IBD development demonstrates the importance of microbial perturbation in disease development [8,9]. Recent genetic discoveries reinforce the essential role for host defence against infection in IBD pathogenesis [10]. 
The biological importance of the gastrointestinal microbiota and its symbiotic relationship with the human host is now firmly established [11,12]. It is increasingly clear that disturbance of the resident microbiota can induce human disease, with the most studied example being the "dysbiosis" of IBD and its resultant inflammation [13,14]. The route from health to IBD through dysbiosis is unclear but may involve a trigger event such as bacterial infection $[15,16]$. We recently postulated that Proteobacteria with adherent and invasive properties may exploit weaknesses in host defences to drive this dysbiotic change [16]. Helicobacter species (microaerophilic members of the Epsilonproteobacteria; "microaerophilic" describing bacteria that thrive in low oxygen concentrations) have been shown to initiate IBD in both rodent and primate models and may also be implicated in infectious proctitis in humans [17]. Conflicting evidence exists from human studies to support Helicobacter as agents in human IBD [18-26]; nevertheless the compelling animal data has made the genus worthy of consideration as a potential pathogen in IBD. Campylobacter concisus (another microaerophilic Epsilonproteobacterium) was cultured from mucosal biopsies from a paediatric CD patient by Zhang et al [27]. This organism has since been shown to be more prevalent in IBD and to be capable of adhering to and invading epithelial cells and driving a pro-inflammatory change [28-31].

Much of the current literature on IBD microbiology utilises convenient cohorts of patients with established disease, potentially introducing major confounders when interpreting results [32]. Paediatric IBD offers an opportunity to explore these problems, since children are relatively free of additional significant comorbidities and are generally treatment naïve at IBD diagnosis. For these reasons we set up the "Bacteria in Inflammatory bowel disease in Scottish Children Undergoing Investigation before Treatment" (BISCUIT) study, with the specific aims of:

1) Recruiting a robustly described, prospective clinical cohort of newly presenting children with untreated IBD alongside children with normal colons as controls

\section{8 approached

\[ \begin{array}{l}10 \text { excluded as antibiotics }<3 \text { months } \\ 1 \text { excluded as steroids }<3 \text { months } \\ 6 \text { recruitment not possible } \\ 8 \text { refused consent }\end{array} \] \\ 103 consented

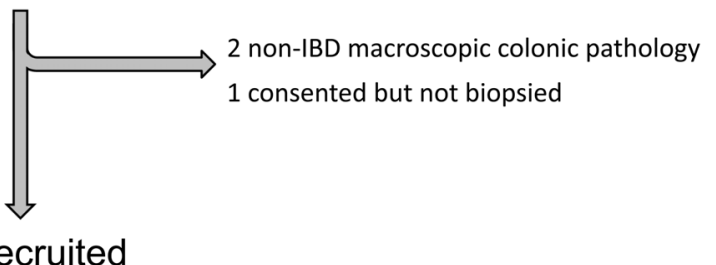 \\ 100 recruited}

Figure 1. Recruitment flowchart of recruits to BISCUIT study. Those where recruitment was not possible were approached by post but could not then be recruited on their day of colonoscopy. The one child consented but not biopsied was due to unavailability of the investigator on the day in question. doi:10.1371/journal.pone.0058825.g001
2) Isolating and identifying microaerophilic bacteria (particularly Helicobacter and Campylobacter) that may be of clinical relevance at the onset of IBD

3) Confirming the true prevalence of specific microaerophilic organisms within the colonic mucosa by molecular methods.

The BISCUIT study recruited 100 Scottish children over a 30 month period. The data contained within this paper documents the isolation and identification of microaerophilic bacteria alongside the molecular (true) prevalence of Helicobacter and Campylobacter species and Sutterella wadsworthensis within colonic biopsies from the entire BISCUIT cohort. In a complementary but distinct analysis we previously published a full hypothesis-free bacterial diversity assessment using pyrosequencing on a subset of the cohort (37 BISGUIT subjects in total) [32].

\section{Methods}

Patients were recruited to the BISCUIT study from elective colonoscopy lists in three paediatric centres (Royal Aberdeen Children's Hospital, Aberdeen; Royal Hospital for Sick Children, Glasgow and Ninewells Hospital, Dundee). An approach with study information was made either on the day of admission (the day before endoscopy) or by post in advance of admission. Patients were excluded if they received systemic antibiotics or steroids 3 months prior to their colonoscopy, immunosuppression at any time, or if they had a previous IBD diagnosis. IBD investigations were as per the Porto criteria. IBD diagnosis and phenotype were assigned with reference to the Lennard-Jones, Montreal and Paris criteria (Table S2) [33-36]. Comprehensive clinical data were also collected at recruitment by a single investigator through use of a standardised verbal questionnaire.

Initial recruitment was into two macroscopically-defined categories, those with likely IBD, at first presentation, with macroscopic colonic inflammation and those undergoing colonoscopy who subsequently had a normal colon macroscopically. Final diagnosis and disease categorisation was assigned once endoscopic, histological and radiological investigations were complete after a minimum of six months follow-up.

\section{Ethics Statement}

Ethical approval was granted by North of Scotland Research Ethics Service (09/S0802/24) on behalf of all participating centres and written informed consent was obtained from the parents of all subjects. Informed assent was also obtained from older children who were deemed capable of understanding the nature of the study.

This study is publically registered on the United Kingdom Clinical Research Network Portfolio (9633).

Biopsies were taken from a single site, from the distal colon in controls (rectum/sigmoid) or from the most distal inflamed site in those with colonic inflammation. 5-6 biopsies were collected using standard endoscopic forceps from all recruits. 1-2 biopsies were used for microaerophilic culture work by transferring these biopsies immediately into individual $2 \mathrm{ml}$ screw-top containers with $\sim 700 \mu \mathrm{l}$ Brucella broth which were incubated at room temperature until plated. 2-3 biopsies were collected for DNA analysis into a sterile $1.5 \mathrm{ml}$ Eppendorf container and placed immediately onto ice before transfer to $-80^{\circ} \mathrm{C}$ storage. The remaining biopsy was collected in paraformaldehyde for future fluorescent in-situ hybridisation studies.

Culture work was performed as described in Mukhopadhya et al [37] utilising five selective plates and one plain blood agar plate, each incubated in microaerophilic gas conditions generated by 


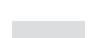

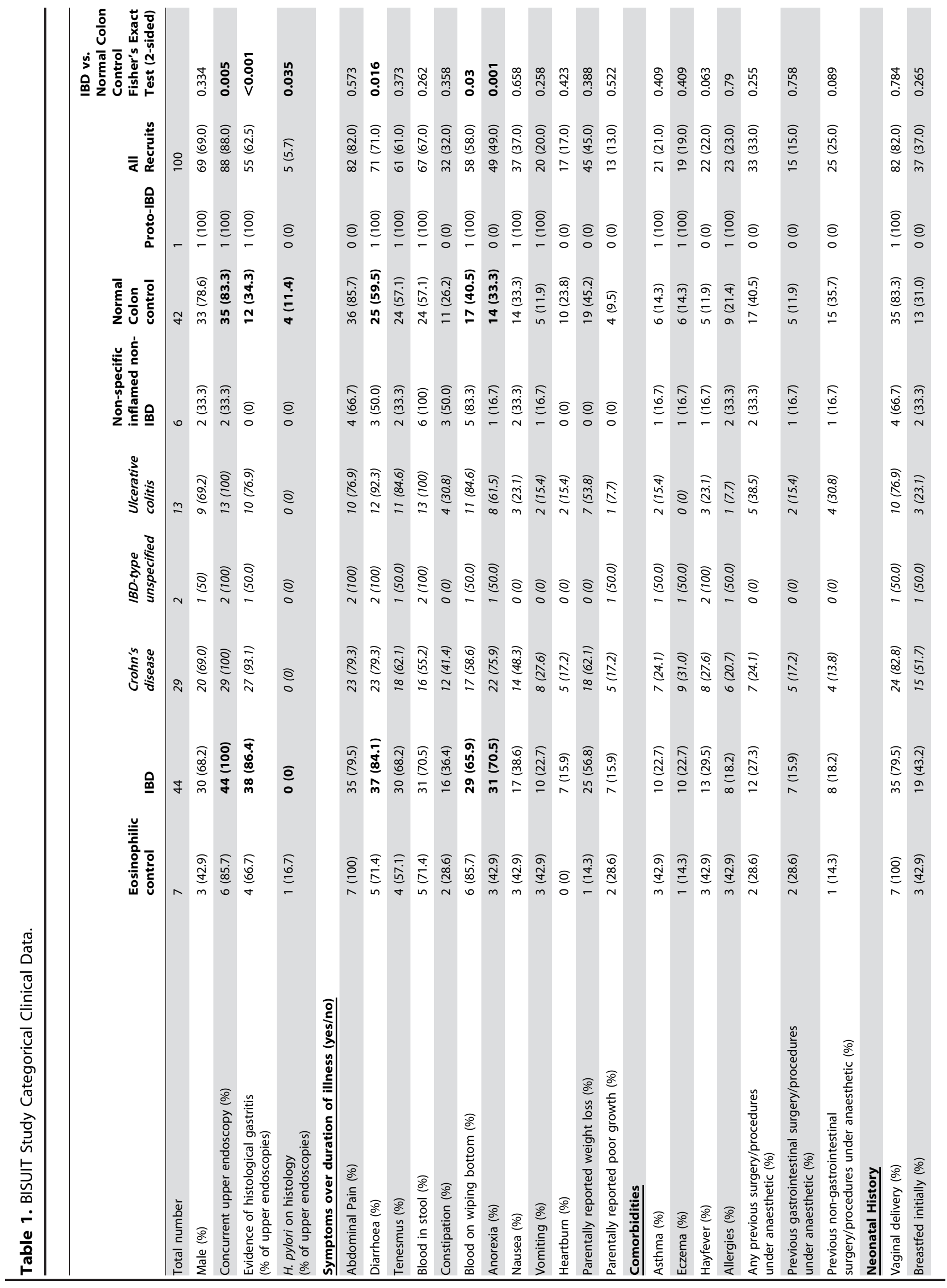




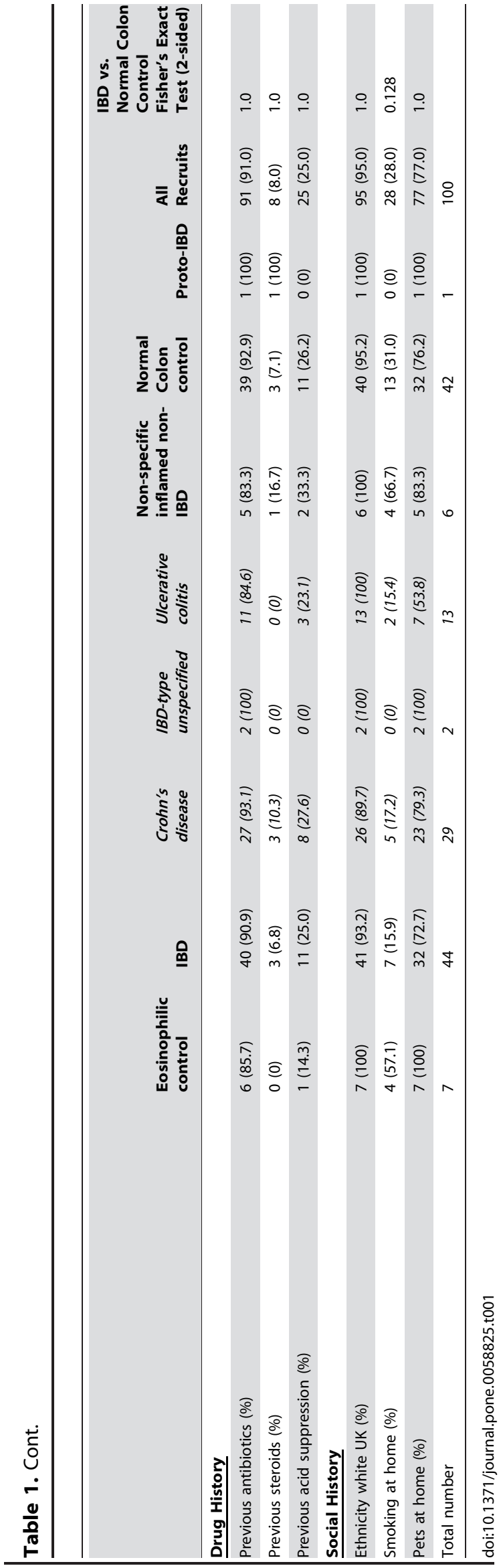

Anoxomat ${ }^{\circledR}$ (Mart ${ }^{\circledR}$ Microbiology, Drachten, Netherlands) and reviewed twice weekly for up to one month. Gram-negative and oxygen sensitive (by virtue of failed subculture in room air) bacterial isolates were identified by sequencing of the $16 \mathrm{~S}$ rRNA gene. A minimum read length of $400 \mathrm{bp}$ was obtained for attributing bacterial identities, the result of which was searched against the NCBI BLAST database (http://blast.ncbi.nlm.nih. gov/Blast.cgi).

DNA extraction of mucosal biopsies was performed using the commercially available Qiagen QIAamp Mini kit (Qiagen, Crawley, UK) with minor modifications as described previously [25]. A test polymerase chain reaction (PCR) with biopsy DNA was performed utilising universal bacterial primers to confirm the suitability of the DNA for further analysis (Table S1) [38]. Conventional PCR was undertaken to determine the prevalence of Helicobacter genus, Campylobacter genus and Sutterella wadsworthensis using primers and conditions described previously (Table S1) [25,30,37]. PCR products from Helicobacter and Campylobacter genus reactions were either directly sequenced on an Applied Biosystems model 3730 automated capillary DNA sequencer or cloned first into JM109 competent cells with pGEM-T-easy vector if sequence analyses indicated a mixed sequencing profile [30].

Helicobacter pylori serology was performed using the Premier $H$. pylori enzyme immunoassay which detects IgG antibody (Meridian Bioscience).

All statistical comparisons were undertaken using SPSS Statistics version 20 (IBM Software 2010).

\section{Results}

128 Scottish children were approached for the study with 100 being recruited (Figure 1). Final categorisation was based on a thorough review of macroscopic, microscopic and available radiological data and is presented in Table 1 and Table 2 alongside categorical, demographic and numerical clinical data respectively. 44 IBD subjects were diagnosed as CD (29), ulcerative colitis (UC) (13) and IBD-type unclassified (IBD-U) (2). Individual IBD phenotypes are shown in Table S2. Granulomata were identified in at least one biopsy site in 21 of $29(72.4 \%)$ CD recruits. A priori, the intention was to compare IBD recruits against those with a normal colon, however in order to achieve this, those with microscopic pathology were further subcategorised. "Normal colon control" subjects had both a macroscopically and microscopically normal colon. "Eosinophilic controls" had histologically significant eosinophilic infiltration of their colonic mucosa in at least one site. "Non-specific inflamed, non-IBD" subjects had microscopic evidence of inflammation but insufficient grounds for an IBD diagnosis. The single "proto-IBD" recruit would have been classified within the "eosinophilic control" category but has since been re-evaluated and has subsequently developed CD. Data from each of these latter three phenotypic groups are presented in full; however statistical analyses compare the IBD and normal colon control groupings only.

Comparisons of clinical data are shown in Table $\mathbf{1}$ and Table 2. Histological gastritis was more common in the IBD cohort than normal colon controls who underwent gastroscopy $(\mathrm{p}<0.001$; Table 1). Conversely, histological identification of $H$. pylori was higher in the normal colon controls and absent in the IBD cohort $(\mathrm{p}=0.035$; Table 1).

Of 555 attempted bacterial subcultures, 494 demonstrated some growth within 7 days, with 414 yielding sufficient growth to allow Gram-staining and aerobic subculture challenge to be completed (Figure 2). 129 bacterial isolates met the requirements for further 


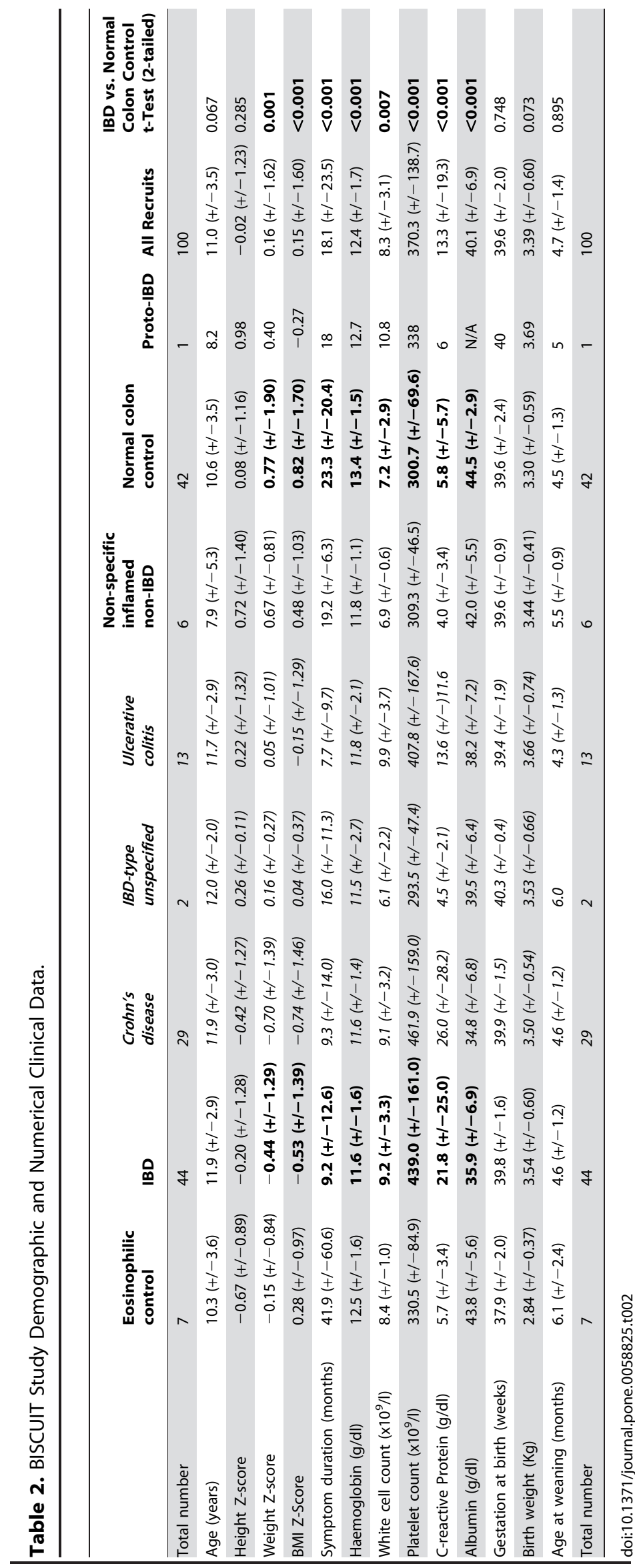




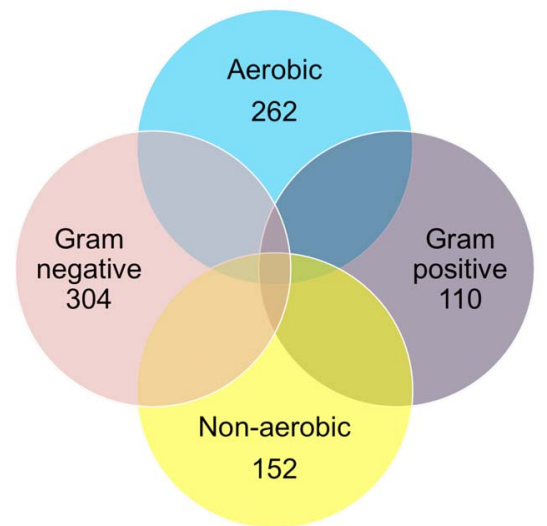

Figure 2. Basic phenotypic assessment of 414 bacterial isolates obtained from the paediatric colonic mucosa. 129 were both Gram-negative and non-aerobic, of which 114 were formally identified by sequencing.

doi:10.1371/journal.pone.0058825.g002 identification (Gram-negative but failed aerobic subculture). Of these, 114 yielded sufficient growth for DNA based identification. 112 were confirmed as Gram-negative microaerophilic bacteria after formal sequence identification. The formal identities of these 112, including 73 distinct patient isolates, are presented in Table 3. The identities of the remaining two isolates matched two separate Gram-positive species (Bifidobacterium longum and Enterococcus faecalis) hence they were removed.

PCR prevalence data and Helicobacter pylori serology results for each of the phenotypic categories are shown in Table 4 and for each of the subjects in Table S2. There was no significant difference in PCR prevalence for Helicobacter, Campylobacter or Sutterella wadsworthensis between the IBD cohort and normal colon controls (Table 4). No H. pylori seropositive subject was positive for Helicobacter PCR and vice-versa. Table 5 documents Campylobacter PCR sequencing data to species-level stratified by clinical phenotype. It is apparent from the data that individuals can

Table 3. Bacterial Isolates Identified based on $16 \mathrm{~S}$ rDNA sequencing.

\begin{tabular}{|c|c|c|c|c|c|}
\hline Isolate & $\begin{array}{l}\text { Number of Subcultures } \\
\text { Obtained (May include } \\
\text { duplicates from same patient } \\
\text { derived from } \\
\text { different growth media) }\end{array}$ & $\begin{array}{l}\text { Distinct } \\
\text { Patient } \\
\text { Isolates }\end{array}$ & Source & $\begin{array}{l}16 S \\
\text { Sequence } \\
\text { Length }\end{array}$ & $\begin{array}{l}\text { Percentage } \\
\text { Similarity } \\
\text { on BLAST }\end{array}$ \\
\hline Alistipes finegoldii & 1 & 1 & IBD-type unspecified & 515 bp & $100 \%$ \\
\hline Bacteroides caccae & 3 & 2 & $\begin{array}{l}\text { Non-specific inflamed } \\
\text { non-IBD (1), IBD-type } \\
\text { unspecified (1) }\end{array}$ & $513-795$ bp & $99 \%$ \\
\hline Bacteroides dorei & 1 & 1 & Normal colon control & 684 bp & $100 \%$ \\
\hline Bacteroides fragilis & 1 & 1 & Crohn's disease & 526 bp & $99 \%$ \\
\hline Bacteroides nordii & 1 & 1 & Normal colon control & 566 bp & $99 \%$ \\
\hline Bacteroides ovatus & 2 & 2 & Normal colon control (2) & $433 \mathrm{bp}$ & $99 \%$ \\
\hline Bacteroides salyersiae & 2 & 1 & IBD-type unspecified (2) & 697 bp, 823 bp & $99 \%$ \\
\hline Bacteroides thetaiotaomicron & 1 & 1 & Crohn's disease & 415 bp & $100 \%$ \\
\hline Bacteroides uniformis & 1 & 1 & Normal colon control & 503 bp & $99 \%$ \\
\hline Butyricimonas virosa & 2 & 2 & $\begin{array}{l}\text { Normal colon control (1), IBD-type } \\
\text { unspecified (1) }\end{array}$ & 569 bp, 676 bp & $98-99 \%$ \\
\hline Campylobacter concisus & 6 & 3 & Crohn's disease (2), Ulcerative colitis (1) & $1357-1423$ bp & $99-100 \%$ \\
\hline Campylobacter curvus & 1 & 1 & Normal colon control & 1537 bp & $99 \%$ \\
\hline Campylobacter lari & 1 & 1 & Normal colon control & 647 bp & $100 \%$ \\
\hline Campylobacter rectus & 1 & 1 & Normal colon control & 401 bp & $100 \%$ \\
\hline Campylobacter showae & 6 & 3 & Normal colon control (2), Crohn's disease (1) & $1325-1422$ bp & $99 \%$ \\
\hline Eikenella corrodens & 2 & 1 & Crohn's disease & $776-802$ bp & $99-100 \%$ \\
\hline Haemophilus parainfluenzae & 8 & 7 & $\begin{array}{l}\text { Crohn's disease (3), Ulcerative colitis (2), } \\
\text { Normal colon control (2) }\end{array}$ & $455-807$ bp & $99-100 \%$ \\
\hline Odoribacter splanchnicus & 1 & 1 & Eosinophilic control & 819 bp & $99 \%$ \\
\hline Parabacteroides distasonis & 7 & 7 & $\begin{array}{l}\text { Normal colon control (6), } \\
\text { Ulcerative colitis (1) }\end{array}$ & $412-786$ bp & $99 \%$ \\
\hline Sutterella wadsworthensis & 61 & 32 & $\begin{array}{l}\text { Normal colon control (11), Crohn's } \\
\text { disease (8), Ulcerative colitis (6), } \\
\text { Eosinophilic control (3), } \\
\text { Non-specific inflamed non-IBD (2), } \\
\text { IBD-type unspecified (1), Proto-IBD (1) }\end{array}$ & $411-1423$ bp & $97-100 \%$ \\
\hline $\begin{array}{l}\text { Terrahaemophilus } \\
\text { aromaticivorans }\end{array}$ & 3 & 3 & $\begin{array}{l}\text { Crohn's disease (1), Ulcerative } \\
\text { colitis (1), Normal colon control (1) }\end{array}$ & 554672 bp & $99 \%$ \\
\hline Total & 112 & 73 & & & \\
\hline
\end{tabular}


Table 4. PCR Prevalence and Helicobacter pylori Serology Data from BISCUIT Study.

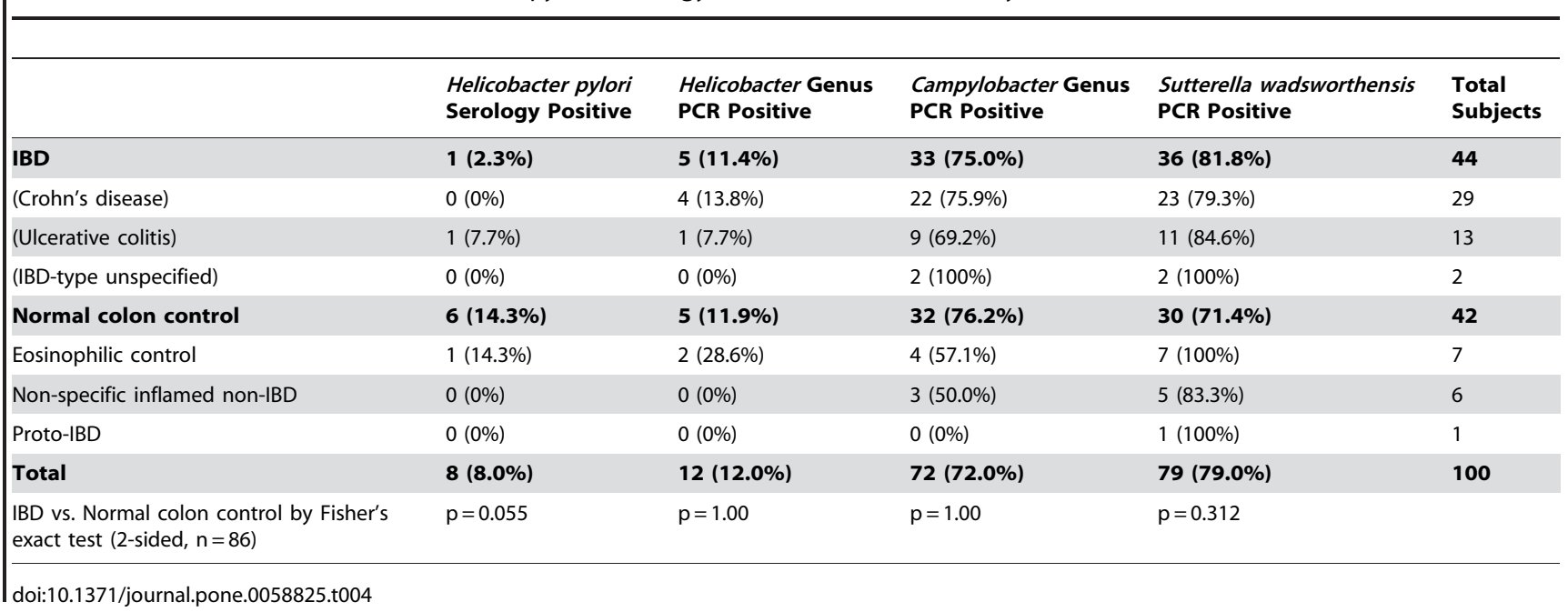

harbour multiple distinct species. Of the 72 positive subjects, 44 had a single Campylobacter identified with two species being identified in 17 and three species in the remaining 11 (Table 6). Campylobacter curous, Campylobacter gracilis and Campylobacter ureolyticus were never identified in isolation. The Helicobacter sequencing data was far less complex with only 12 subjects yielding positive PCR product. Of these, 5 were from normal colon controls, 5 from IBD (4 CD, $1 \mathrm{UC}$ ) and 2 were from eosinophilic controls. After sequencing the PCR product, 8 of the 12 (4 normal colon controls, 2 IBD- both CD, 2 eosinophilic controls) were identified as Wolinella succinogenes, another Epsilonproteobacteria and member of the Helicobacteraceae. The four remaining Helicobacter positive results were not identifiable by direct sequencing and underwent cloning and sequencing analysis. This revealed the presence of both $W$. succinogenes and Helicobacter brantae (from a CD patient) and confirmed the presence of Helicobacter hepaticus from a second CD patient. The two remaining patient samples remained unidentifiable despite repeated cloning attempts.

\section{Discussion}

This study comprehensively describes the microaerophilic microbiota of the paediatric colon with specific reference to untreated, new-onset paediatric IBD and also those with a normal colon. Our main findings are of a high molecular prevalence and culture recovery rate of unusual Campylobacter species and $S$. wadsworthensis and of a low molecular prevalence of Helicobacteraceae. There was no difference in the prevalence of microaerophilic species between IBD patients and controls. We acknowledge that the microaerophilic microbiota comprises a relatively small proportion of the bacterial community present within the colon, with the majority of species being obligate anaerobes. Evidence supporting a role for these microaerophilic species in IBD cannot however be ignored and they are therefore worthy of targeted study.

The possibility that Helicobacter species may be involved in IBD pathogenesis is an intriguing one that has been the subject of many studies and much debate [17-26]. The earliest observation that $H$. pylori seropositivity is negatively associated with IBD [39] was not directly replicated in this study, however in our recruits undergoing concurrent upper gastrointestinal endoscopy, microscopic evidence of $H$. pylori was entirely absent from the IBD cohort and significantly higher in normal colon controls. C. concisus is an organism that has generated significant interest following culture recovery from the colon of children with CD, with subsequent work describing the adherent, invasive and proinflammatory capabilities of the organism [27,29]. Other authors have suggested that the organism may be increased in IBD against controls [28,30,31], yet our data contradicts this finding by demonstrating a comparable prevalence between the two groupings. Our data are the first to specifically address these organisms at the onset of IBD. The low prevalence of Helicobacteraceae and equivalent prevalence of $C$. concisus at the onset of IBD which we have shown makes it unlikely that these organisms have a role in disease pathogenesis in children; nevertheless their identification in the colon of subjects with established disease in other studies suggests that roles within disease chronicity may still be possible.

We have described a surprisingly diverse and prevalent colonisation of the paediatric colon with unusual Campylobacter species, including the possibility of up to three distinct species coexisting in close proximity in the same individual. The importance of these Campylobacter in paediatric health and disease warrants further consideration, particularly given the unquestionable pathogenicity of Campylobacter jejuni and Campylobacter coli, the two most commonly identified representatives of the genus in paediatric faecal samples [40]. Our data suggest a more diverse and prevalent colonic colonisation with Campylobacter species than previously reported. This finding may be a direct reflection of the sampling bias introduced by studying faeces alone which is known to represent a distinct ecosystem [41]. We have shown that unusual Campylobacter species can be identified in the colon of 7/10 children and cultured successfully from 8/100. Additional studies are required to increase the culture yield for these organisms and to characterise individual species and further outline their role in health and disease.

Sutterella wadsworthensis is an organism that has rarely been discussed in the literature, having first been described as a potential gastrointestinal pathogen in 1996 [42]. We recently examined the molecular prevalence of this organism in an adult study including those with UC and those with a normal colon and 


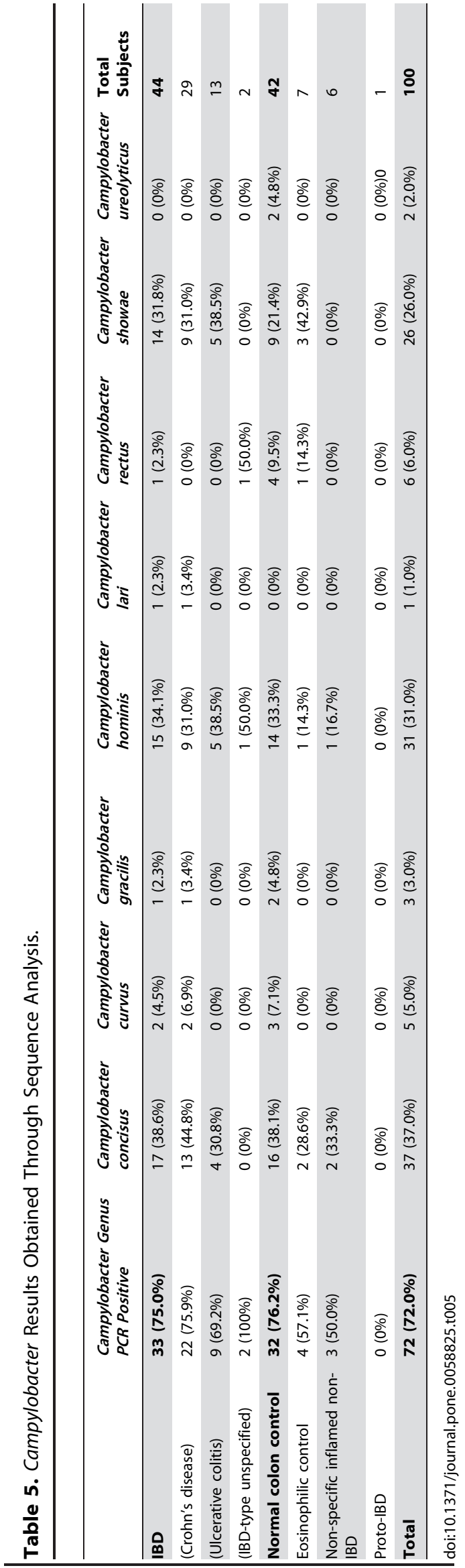

found a similar and high prevalence in both groups [37]. Phenotypic and genotypic comparison of isolates suggested no difference between the two clinical groups. We suggested therefore that $S$. wadsworthensis is likely a common intestinal commensal. A recent paper on 32 children has however linked $S$. wadsworthensis to autism [43], generating considerable discussion in the process $[44,45]$. We again find within the paediatric population, that this organism is commonly identified and easily recovered from biopsies by culture. Given the high prevalence (79\% overall) of this organism in our whole cohort, we consider it unlikely that it is specific to the autistic intestine as has been suggested. This of course does not exclude differential immunological reaction to the organism within autistic children, which requires further exploration.

The limitations of this study cohort have been discussed previously [32] and will be repeated here briefly. All subjects received stimulant bowel preparation before colonoscopy. Although this may have altered the bacteria within the colonic mucosa, the treatment was given to all and would likely act equivalently between groups. A study where children undergo colonoscopy under general anaesthetic without bowel preparation would be unethical. The controls in this study were all children undergoing colonoscopy for gastrointestinal symptoms. There were therefore no strictly "healthy" controls. We have tried to address this by describing our subcategorisation of recruits in detail and selecting only those with a macroscopically and microscopically normal colon as our main control group.

This study rejects a role for the microaerophilic bacteria Helicobacter, Campylobacter and S. wadsworthensis at the initiation of paediatric IBD, however hypothesis-free analysis of a subgroup of the same study using pyrosequencing has shown that differences in the IBD microbiota are apparent at the onset of disease. Of particular interest to the culture results from this study, we have shown that Parabacteroides appear to be significantly reduced in UC against normal colon controls [32]. This appears to be reflected further in our culture recovery rate of Parabacteroides distasonis reported here $(6$ isolates derived from normal colon controls against a single UC isolate). This observation would fit with the discoveries that $P$. distasonis antigens can attenuate murine colitis and are specifically recognised by colonic $\mathrm{T}$ regulatory cells [46,47]. $P$. distasonis might be suitable for consideration as a probiotic bacterium for topical colonic treatment in UC.

\section{Conclusion}

This study has provided novel data describing a hitherto unrecognised high prevalence and diversity of unusual Campylobacter species and a high prevalence of $S$. wadsworthensis in the paediatric colon. We have also shown a low prevalence of organisms within the Helicobacteraceae. Although we have not demonstrated any organisms of likely significance to IBD pathogenesis, we have explored two likely candidate genera specifically at the onset of disease and demonstrated that their involvement in disease initiation is unlikely. Our data on S. wadsworthensis refutes the suggestion that this organism is specific to the paediatric autistic intestine, and alongside our previous work, suggests this organism is a common intestinal commensal. Our isolates of $P$. distasonis from the normal paediatric colon might be suitable for consideration as probiotics. We have shown that a targeted culture and molecular microbiology study in the paediatric population can demonstrate surprising results and offer a high yield for the enumeration of unusual and rarely described organisms. 
Table 6. Campylobacter Sequencing Results at Species-Level by Number of Species per Subject.

\begin{tabular}{|c|c|c|}
\hline Single Species & $\begin{array}{l}\text { Number of } \\
\text { Subjects }\end{array}$ & Source \\
\hline Campylobacter concisus & 18 & $\begin{array}{l}\text { Normal colon control (6), Crohn's disease (8), Ulcerative colitis (2), Non-specific inflamed } \\
\text { non-IBD (2) }\end{array}$ \\
\hline Campylobacter hominis & 10 & $\begin{array}{l}\text { Normal colon control (5), Crohn's disease (1), Ulcerative colitis (2), Non-specific inflamed } \\
\text { non-IBD (1), IBD-type unspecified (1) }\end{array}$ \\
\hline Campylobacter lari & 1 & Crohn's disease (1) \\
\hline Campylobacter rectus & 5 & Normal colon control (3), Eosinophilic control (1), IBD-type unspecified (1) \\
\hline Campylobacter showae & 10 & Normal colon control (5), Crohn's disease (2), Ulcerative colitis (2), Eosinophilic control (1 \\
\hline Total & 44 & \\
\hline Two Species & Number of Subjects & Source \\
\hline $\begin{array}{l}\text { Campylobacter } \\
\text { concisus+Campylobacter curvus }\end{array}$ & 2 & Normal colon control (1), Crohn's disease (1) \\
\hline $\begin{array}{l}\text { Campylobacter } \\
\text { concisus+Campylobacter hominis }\end{array}$ & 5 & Normal colon control (4), Crohn's disease (1) \\
\hline $\begin{array}{l}\text { Campylobacter } \\
\text { concisus+Campylobacter showae }\end{array}$ & 2 & Normal colon control (1), Eosinophilic control (1) \\
\hline $\begin{array}{l}\text { Campylobacter } \\
\text { gracilis+Campylobacter hominis }\end{array}$ & 1 & Crohn's disease (1) \\
\hline $\begin{array}{l}\text { Campylobacter } \\
\text { gracilis+Campylobacter showae }\end{array}$ & 1 & Normal colon control (1) \\
\hline $\begin{array}{l}\text { Campylobacter } \\
\text { hominis+Campylobacter showae }\end{array}$ & 5 & Crohn's disease (4), Ulcerative colitis (1) \\
\hline $\begin{array}{l}\text { Campylobacter } \\
\text { hominis+Campylobacter ureolyticus }\end{array}$ & 1 & Normal colon control (1) \\
\hline Total & 17 & \\
\hline Three Species & Number of Subjects & Source \\
\hline $\begin{array}{l}\text { Campylobacter concisus+Campylobacter } \\
\text { curvus+Campylobacter showae }\end{array}$ & 2 & Normal colon control (1), Crohn's disease (1) \\
\hline $\begin{array}{l}\text { Campylobacter concisus+Campylobacter } \\
\text { curvus+Campylobacter hominis }\end{array}$ & 1 & Normal colon control (1) \\
\hline $\begin{array}{l}\text { Campylobacter concisus+Campylobacter } \\
\text { gracilis+Campylobacter hominis }\end{array}$ & 1 & Normal colon control (1) \\
\hline $\begin{array}{l}\text { Campylobacter concisus+Campylobacter } \\
\text { hominis+Campylobacter rectus }\end{array}$ & 1 & Normal colon control (1) \\
\hline $\begin{array}{l}\text { Campylobacter concisus+Campylobacter } \\
\text { hominis+Campylobacter showae }\end{array}$ & 5 & Crohn's disease (2), Ulcerative colitis (2), Eosinophilic control (1) \\
\hline $\begin{array}{l}\text { Campylobacter hominis+Campylobacter } \\
\text { showae+Campylobacter ureolyticus }\end{array}$ & 1 & Normal colon control (1) \\
\hline Total & 11 & \\
\hline
\end{tabular}

\section{Supporting Information}

Table S1 PGR Primers Used in This Study. (DOCX)

Table S2 BISGUIT Patient Cohort PCR and H. pylori Serology Results for Individual Recruits with Phenotype.

(DOCX)

\section{Acknowledgments}

Mrs Karen McIntyre was invaluable in identifying patients for recruitment in Dundee. Mrs Ann Morrice provided administrative support in

\section{References}

1. Van Limbergen J, Russell RK, Drummond HE, Aldhous MC, Round NK, et al. (2008) Definition of phenotypic characteristics of childhood-onset inflammatory bowel disease. Gastroenterology. 135(4): 1114-1122.
Aberdeen. We appreciate the generosity of the families who freely gave their time and samples to make this study possible and the theatre staff of all centres who allowed time for sample collection during busy endoscopy lists.

\section{Author Contributions}

Identified and recruited patients: RH WMB SL GM DKC AB JB DF PM RR. Conceived and designed the experiments: RH JT RR EE GH. Performed the experiments: RH SB IM KS CN. Analyzed the data: RH RR GH. Wrote the paper: RH RR GH.

2. Kugathasan S, Saubermann LJ, Smith L, Kou D, Itoh J, et al. (2007) Mucosal T-cell immunoregulation varies in early and late inflammatory bowel disease. Gut. 56(12): 1696-1705. 
3. Imielinski M, Baldassano RN, Griffiths A, Russell RK, Annese V, et al. (2009) Common variants at five new loci associated with early-onset inflammatory bowel disease. Nat Genet. 41: 1335-1340.

4. Henderson P, Hansen R, Cameron FL, Gerasimidis C, Rogers P, et al. (2012) Rising incidence of pediatric inflammatory bowel disease in Scotland. Inflamm Bowel Dis. 18(6): 999-1005.

5. Hope B, Shahdadpuri R, Dunne C, Broderick AM, Grant T, et al. (2012) Rapid rise in incidence of Irish paediatric inflammatory bowel disease. Arch Dis Child. 97(7): 590-594.

6. Martín-de-Carpi J, Rodríguez A, Ramos E, Jiménez S, Martínez-Gómez MJ, et al. (2012) Increasing incidence of pediatric inflammatory bowel disease in Spain (1996-2009): The SPIRIT registry. Inflamm Bowel Dis. doi: 10.1002/ ibd.22980.

7. Benchimol EI, Fortinsky KJ, Gozdyra P, Van den Heuvel M, Van Limbergen J, et al. (2011) Epidemiology of pediatric inflammatory bowel disease: A systematic review of international trends. Inflamm Bowel Dis. 17(1): 423-439.

8. Shaw SY, Blanchard JF, Bernstein CN (2010) Association between the use of antibiotics in the first year of life and pediatric inflammatory bowel disease. Am J Gastroenterol. 105(12): 2687-2692.

9. Kronman MP, Zaoutis TE, Haynes K, Feng R, Coffin SE (2012) Antibiotic exposure and IBD development among children: A population-based cohort study. Pediatrics. 130(4): e794-e803.

10. Jostins L, Ripke S, Weersma RK, Duerr RH, McGovern DP, et al. (2012) Hostmicrobe interactions have shaped the genetic architecture of inflammatory bowel disease. Nature. 491(7422): 119-124.

11. Huttenhower C, Gevers D, Knight R, Abubucker S, Badger JH, et al. (2012) Structure, function and diversity of the healthy human microbiome. Nature. 486(7402): 207-214.

12. Qin J, Li R, Raes J, Arumugam M, Burgdorf KS, et al. (2010) A human gut microbial gene catalogue established by metagenomic sequencing. Nature. 464(7285): 59-65.

13. Tamboli CP, Neut C, Desreumaux P, Colombel JF (2004) Dysbiosis in inflammatory bowel disease. Gut. 53(1): 1-4.

14. Round JL, Mazmanian SK (2009) The gut microbiota shapes intestinal immune responses during health and disease. Nat Rev Immunol. 9: 313-323.

15. Hansen R, Thomson JM, El-Omar EM, Hold GL (2010) The role of infection in the aetiology of inflammatory bowel disease. J Gastroenterol. 45(3): 266-276.

16. Mukhopadhya I, Hansen R, El-Omar EM, Hold GL (2012) IBD- what role do proteobacteria play? Nat Rev Gastroenterol Hepatol. 9(4): 219-230.

17. Hansen R, Thomson JM, Fox JG, El-Omar EM, Hold GL (2010) Could Helicobacter organisms cause inflammatory bowel disease? FEMS Immunol Med Microbiol. 61(1): 1-14.

18. Bell SJ, Chisholm SA, Owen RJ, Borriello SP, Kamm MA (2003) Evaluation of Helicobacter species in inflammatory bowel disease. Aliment Pharmacol Ther. 18(5): 481-486.

19. Grehan M, Danon S, Lee A, Daskalopoulos G, Mitchell H (2004) Absence of mucosa-associated colonic Helicobacters in an Australian urban population. J Clin Microbiol. 42(2): 874-876.

20. Bohr URM, Glasbrenner B, Primus A, Zagoura A, Wex T, et al. (2004) Identification of enterohepatic Helicobacter species in patients suffering from inflammatory bowel disease. J Clin Microbiol. 42(6): 2766-2768.

21. Zhang L, Day A, McKenzie G, Mitchell H (2006) Nongastric Helicobacter species detected in the intestinal tract of children. J Clin Microbiol. 44(6): 2276 2279.

22. Man SM, Zhang L, Day AS, Leach S, Mitchell H (2008) Detection of enterohepatic and gastric Helicobacter species in fecal specimens of children with Crohn's disease. Helicobacter. 13(4): 234-238.

23. Laharie D, Asencio C, Asselineau J, Bulois P, Bourreille A, et al. (2009) Association between entero-hepatic Helicobacter species and Crohn's disease: A prospective cross-sectional study. Aliment Pharmacol Ther. 30(3): 283-293.

24. Keenan JI, Beaugie CR, Jasmann B, Potter HC, Collett JA, et al. (2010) Helicobacter species in the human colon. Colorec Dis. 12(1): 48-53.

25. Thomson JM, Hansen R, Berry SH, Hope ME, Murray GI, et al. (2011) Enterohepatic Helicobacter in ulcerative colitis: Potential pathogenic entities? PLoS One. 6(2): e17184.

26. Kaakoush NO, Holmes J, Octavia S, Man SM, Zhang L, et al. (2010) Detection of Helicobacteraceae in intestinal biopsies of children with Crohn's disease. Helicobacter. 15(6): 549-557.

27. Zhang L, Man SM, Day AS, Leach ST, Lemberg DA, et al. (2009) Detection and isolation of Campylobacter species other than $\mathrm{C}$. jejuni from children with Crohn's disease. J Clin Microbiol. 47(2): 453-455.
28. Man SM, Zhang L, Day AS, Leach ST, Lemberg DA, et al. (2010) Campylobacter concisus and other Campylobacter species in children with newly diagnosed Crohn's disease. Inflamm Bowel Dis. 16(6): 1008-1016.

29. Man SM, Kaakoush NO, Leach ST, Nahidi L, Lu HK, et al. (2010) Host attachment, invasion, and stimulation of proinflammatory cytokines by Campylobacter concisus and other non-Campylobacter jejuni Campylobacter species. J Infect Dis. 202(12): 1855-1865.

30. Mukhopadhya I, Thomson JM, Hansen R, Berry SH, El-Omar EM, et al. (2011) Detection of Campylobacter concisus and other Campylobacter species in colonic biopsies from adults with ulcerative colitis. PLoS One. 6(6): e21490.

31. Mahendran V, Riordan SM, Grimm MC, Tran TA, Major J, et al. (2011) Prevalence of Campylobacter species in adult Crohn's disease and the preferential colonization sites of Campylobacter species in the human intestine. PLoS One. 6(9): e25417.

32. Hansen R, Russell RK, Reiff C, Louis P, McIntosh F, et al. (2012) Microbiota of de-novo pediatric IBD: Increased Faecalibacterium prausnitzii and reduced bacterial diversity in Crohn's but not ulcerative colitis. Am J Gastroenterol. 107(12): 1913-1922.

33. Lennard-Jones JE (1989) Classification of inflammatory bowel disease. Scand J Gastroenterol. 24(S170): 2-6.

34. IBD Working Group of the European Society for Paediatric Gastroenterology, Hepatology and Nutrition (2005) Inflammatory bowel disease in children and adolescents: Recommendations for diagnosis- the porto criteria. JPGN. 41(1): 17.

35. Silverberg MS, Satsangi J, Ahmad T, Arnott ID, Bernstein CN, et al. (2005) Towards an integrated clinical, molecular and serological classification of inflammatory bowel disease: Report of a working party of the 2005 Montreal world congress of gastroenterology. Can J Gastroenterol. 19(Suppl A): 5A-36A.

36. Levine A, Griffiths A, Markowitz J, Wilson DC, Turner D, et al. (2011) Pediatric modification of the montreal classification for inflammatory bowel disease: The Paris classification. Inflamm Bowel Dis. 1314-1321.

37. Mukhopadhya I, Hansen R, Nicholl CE, Alhaidan Y A, Thomson JM, et al. (2011) A comprehensive evaluation of colonic mucosal isolates of Sutterella wadsworthensis from inflammatory bowel disease. PloS ONE. 6(10): e27076.

38. Hold GL, Pryde SE, Russell VJ, Furrie E, Flint HJ (2002) Assessment of microbial diversity in human colonic samples by $16 \mathrm{~S}$ rDNA sequence analysis. FEMS Microbiol Ecol. 39(1): 33-39.

39. El-Omar E, Penman I, Cruikshank G, Dover S, Banerjee S, et al. (1994) Low prevalence of Helicobacter pylori in inflammatory bowel disease: Association with sulphasalazine. Gut. 35(10): 1385-1388.

40. Lastovica AJ (2000) Efficient isolation of Campylobacteria from stools. J Clin Microbiol. 38(7): 2798-2799.

41. Eckburg PB, Bik EM, Bernstein CN, Purdom E, Dethlefsen L, et al. (2005) Diversity of the human intestinal microbial flora. Science. 308(5728): 16351638 .

42. Wexler HM, Reeves D, Summanen PH, Molitoris E, McTeague M, et al. (1996) Sutterella wadsworthensis gen. nov., sp. nov., bile-resistant microaerophilic campylobacter gracilis-like clinical isolates. Int J Syst Evol Microbiol. 46(1): 252.

43. Williams BL, Hornig M, Parekh T, Lipkin WI (2012) Application of novel PCRbased methods for detection, quantitation, and phylogenetic characterization of Sutterella species in intestinal biopsy samples from children with autism and gastrointestinal disturbances. MBio. 3(1): e00261-11.

44. Benach JL, Li E, McGovern MM (2012) A microbial association with autism. MBio. 3(1): e00019-12.

45. Collins SM, Surette M, Bercik P (2012) The interplay between the intestinal microbiota and the brain. Nature Reviews Microbiology. 10(11): 735-742.

46. Kverka M, Zakostelska Z, Klimesova K, Sokol D, Hudcovic T, et al. (2011) Ora administration of Parabacteroides distasonis antigens attenuates experimental murine colitis through modulation of immunity and microbiota composition. Clinical \& Experimental Immunology. 163(2): 250-259.

47. Lathrop SK, Bloom SM, Rao SM, Nutsch K, Lio CW, et al. (2011) Peripheral education of the immune system by colonic commensal microbiota. Nature. 478(7368): 250-254.

48. Fox JG, Dewhirst FE, Shen Z, Feng Y, Taylor NS, et al. (1998) Hepatic Helicobacter species identified in bile and gallbladder tissue from Chileans with chronic cholecystitis. Gastroenterology. 114(4): 755-763.

49. Grehan M, Tamotia G, Robertson B, Mitchell H (2002) Detection of Helicobacter colonization of the murine lower bowel by genus-specific PCRdenaturing gradient gel electrophoresis. Appl Environ Microbiol. 68(10): 5164 5166 .

50. Linton D, Owen R, Stanley J (1996) Rapid identification by PCR of the genus Campylobacter and of five Campylobacter species enteropathogenic for man and animals. Res Microbiol. 147(9): 707-718. 